\title{
Possessing History and American Innocence: James Baldwin, William F. Buckley, Jr., and the 1965 Cambridge Debate
}

\author{
Daniel Robert McClure Chapman University
}

\begin{abstract}
The 1965 debate at Cambridge University between James Baldwin and William F. Buckley, Jr., posed the question: "Has the American Dream been achieved at the Expense of the American Negro?" Within the contours of the debate, Baldwin and Buckley wrestled with the ghosts of settler colonialism and slavery in a nation founded on freedom and equality. Framing the debate within the longue durée, this essay examines the deep cultural currents related to the American racial paradox at the height of the Civil Rights movement. Underscoring the changing language of white resistance against black civil rights, the essay argues that the Baldwin and Buckley debate anticipated the ways the U.S. would address racial inequality in the aftermath of the civil rights era and the dawn of neoliberalism in the 1970s.
\end{abstract}

Keywords: James Baldwin, William F. Buckley, Jr., culture war, neoliberalism, anti-blackness, white backlash, modernity, slavery, race relations, Civil Rights movement

It was this Africanism, deployed as rawness and savagery, that provided the staging ground and arena for the elaboration of the quintessential American identity ... Autonomy is freedom and translates into the much championed and revered "individualism"; newness translates into "innocence"; distinctiveness becomes difference and the erection of strategies for maintaining it; authority and absolute power become a romantic, conquering "heroism," virility, and the problematic of wielding absolute power over the lives of others. All the rest are made possible by this last, it

James Baldwin Review, Volume 2, 2016 @ The Authors. Published by Manchester University Press and The University of Manchester Library 
would seem—absolute power called forth and played against and within a natural and mental landscape conceived of as a "raw, half-savage world."

Toni Morrison, Playing in the Dark (1992) ${ }^{1}$

The year 1965 materialized as another promising the delivery of continued economic growth two decades into the postwar Keynesian consensus-the set of welfare state policies developed out of the 1930s New Deal which defined the dominant economic and political norms from the 1940s through the $1960 \mathrm{~s}^{2}$ As historian James T. Patterson asserts in his recent book on the year, "No people in the modern history of the world had had it so good." Perhaps reflecting the American "innocence" Morrison associates above with "newness," Patterson's assertion fails to add the qualifier "white" in front of "people," as African Americans and other people of color continued to navigate the restrictions and state-sanctioned violence that defined Jim Crow America. The transformation of America underlined by Patterson is foreground by his title: Eve of Destruction, a popular 1965 folk-rock tune by Barry McGuire. As a description of the era, destruction found expression in the unsettled turbulence that interrupted the celebrations of the good life anchoring the American dream in 1965: the assassination of Malcolm X in February, the violent setbacks for the Civil Rights movement in Selma in March, and the Watts Uprising in August just days after Congress passed the Voting Rights Act. Caught in an inherited as well as selfmade tragedy, the U.S. public at the very height of the postwar American dream continued to fail to account for the ideological and ontological elements sustaining an American dream atop anti-black antagonisms and institutions inherited from the days of slavery. Reproduced across centuries, anti-blackness historically supported an array of rhetoric buttressing a sense of white innocence that obscured the active racial antagonism defining American identity-where free whiteness juxtaposed against enslaved blackness generated a distinction that invented both "difference and the erection of strategies for maintaining it," as Morrison notes above. ${ }^{4}$ These continuously evolving centuries-old practices form an important part of the identity of whiteness. By 1965, the American dream had reimagined this identity through postwar Keynesian policies that offered federally subsidized regeneration of anti-blackness via suburbanization, economic opportunities, and treatment under the law across the United States. ${ }^{5}$ By the end of 1965, it was increasingly obvious that the deep currents of institutional, antiblack racism clearly needed more than legislation to remediate the structural second-class citizenry of African Americans and other people of color across the nation.

One of the leading critics of this period connecting the American dream to antiblackness was the African-American author James Baldwin. Baldwin's systemic critique of the relationship between racial oppression and economics appeared in full force through his 1960s writings and after. In his 1971 dialogue with poet Nikki Giovanni, for example, he outlined the cultural and economic mechanics of anti-blackness: 
it's very hard to recognize that the standards which have almost killed you are really mercantile standards. They're based on cotton; they're based on oil; they're based on peanuts; they're based on profits ... Because, you see, the reason people think it's important to be white is that they think it's important not to be black. They think it's important to be white because white means you are civilized, and being black means you are not civilized ... [W] hat I'm trying to get at is my apprehension of the crisis of this age. The crisis has something to do with identity, and that has something to do with buried history ... People invent categories in order to feel safe. White people invented black people to give white people identity. ${ }^{6}$

In our contemporary era of expanding wealth inequality, especially the racial wealth gap, Baldwin's comments on the intersections of race and economics continue to be relevant. ${ }^{7}$ A particularly important public moment for Baldwin emerged in 1965 when he debated William F. Buckley, Jr., one of the major architects of the conservative swing right that swept American economics and politics through the twenty-first century. This essay situates the 1965 debate as a crucial moment of dialogue reflecting the long-term contradictions of American society, as well as a preview of how the U.S. would address racial inequality as legal restrictions fell as a result of the civil rights legislation of the 1960s. On one hand, a man of Irish descent who was recognized as the era's conservative standard bearer who held no qualms over standing "athwart history, yelling Stop, at a time when no one is inclined to do so" during an era of civil rights activism. ${ }^{8}$ On the other hand, a descendant of former enslaved peoples who pressed his pen into service on behalf of the era's civil rights activism. Using the 1965 debate as a primary focus, and supplemented by later reflections from Baldwin, this essay offers a theoretical outline of the dynamics holding together the relationship between anti-blackness and economic opportunity in the United States.

Sponsored by the Cambridge Union Society, Baldwin's debate with Buckley on 18 February 1965 in England represented an important signpost defining the American paradox of slavery and freedom in the 1960s. The motion was: "Has the American Dream been achieved at the Expense of the American Negro?" With two Cambridge students debating the two sides and an audience of over $700 \mathrm{stu}-$ dents filling the Cambridge Union's debating hall, the event grasped at core cultural components of racial inequality, the history of the African-American experience, and the intersection of these processes with American capitalism. ${ }^{10}$ The program's host, Norman St John-Stevas M.P., described the momentous event, exclaiming:

hundreds of undergraduates and myself, waiting for what could prove one of the most exciting debates in the whole 150 years of the Union history ... I don't think I've ever seen the Union so well attended. There are undergraduates everywhere; they're on the benches, they're on the floor, they're in the galleries. And there are a lot more outside, clamoring to get in.

An excitement resounded through the Cambridge campus as one descendant of Irish ancestry and one descendent of African ancestry would debate the legacies 
of slavery and its connection to economic opportunity in England's former settler colony, the United States. Taped and broadcasted by the National Educational Television Network (the precursor to Public Broadcasting System), the setting was visibly claustrophobic, with a sea of students filling the television screen. The debate's relevancy, in hindsight, signaled an important cultural shift stirring through U.S. society by the end of 1965. Marking the end of institutional American racial reform, 1965 also witnessed the initiation of significant challenges against the further erosion of institutional racism that had become the focus of the black freedom struggle by $1965 .{ }^{11}$ The institutional racism woven through American capitalism remained untouched by the mid-1960s civil rights legislation, which aimed toward gaining access to lunch tables and voting booths. Throughout the debate, the heavy shadow of the American longue durée relationship to slavery and its ideas of anti-blackness pressed heavily upon Baldwin and Buckley's arguments, with their performances in front of the Cambridge audiences unknowingly setting the stage for the post-1960s culture wars.

Historian Fernand Braudel's (1902-85) concept of the longue durée is essential for situating the dynamics of the debate between Baldwin and Buckley. The longue durée offers an important tool for historians to understand and contextualize decades within long-term structures of ideas, sets of policies, and the material outcomes engineered through these processes: a framework encompassing an analysis of history across centuries, noting economic, cultural, and environmental changes which, over time, occur or change slowly, often imperceptibly. ${ }^{12}$ "Mental frameworks," writes Braudel, operating through the longue durée include "all the old habits of thinking and acting, the set patterns which do not break down easily and which, however illogical, are a long time dying." ${ }^{3}$ Like others in the Black Radical Tradition, Baldwin's critique of the American dream implicitly utilized this broad framework in his interrogation of centuries-old ideas, policies, and material outcomes of anti-blackness rooted in slavery. Buckley's defense of the system - the American dream-also utilized these aged vestiges by evoking a network of language and knowledge rooted in the maintenance of the status quo of the nation's institutions. ${ }^{14}$

Both in their early 40s, Baldwin and Buckley represented two different intellectual poles in 1960s America, as well as two distinct understandings of history. Buckley, born into the white conservative Catholic family of an oil baron and lawyer, schooled in France and England, and later married to the daughter of a Canadian industrialist, developed the intellectual framework for the resurgence of conservatism with the establishment of National Review in 1955, and later his television talk show, Firing Line (first airing in 1966). ${ }^{15}$ Buckley was seminal in bringing together the three major strands of the New Right: religious conservatism, libertarianism, and neoconservatism. ${ }^{16}$ Indeed, Buckley helped steer the culture of capitalism away from the dominant set of ideas instilled by the Great Depression and the New Deal, the Second World War, and the postwar Keynesian economics up through the 1960s. Rather than social welfare, Buckley's conservative reimagined a rugged individualism at odds with government intervention-ranging 
from low taxes to a renewal of states' rights regarding social relations. The connection of his libertarian views of freedom from government intervention with the rights of the individual echoes Morrison's observations above: "Autonomy is freedom and translates into the much championed and revered 'individualism."'17 Considering federal action on civil rights to be unconstitutional social engineering, the conservative embrace of colorblindness imagined a new world where people saw, not race, but only people-or individuals. Stressing the freedoms of individuals amidst an age of collapsing institutionalized white supremacy, Buckley helped shape our own contemporary world, defined through the socio-economic system of neoliberalism and its racial ideology of colorblindness.

As a bestselling novelist and essayist, Baldwin grew up poor in Harlem and later left the country to live and write in Europe. ${ }^{18}$ In the midst of gaining international recognition through a series of novels and collections of essays, the Civil Rights movement pulled Baldwin back to the United States in 1957, where he quickly became a sought-after spokesman. A central black intellectual of the time, Baldwin's rhetoric combined his working-class, Christian, Harlem background with his ability to "speak the language of the white intelligentsia." ${ }^{19}$ In a series of non-fiction works, Baldwin's critiques during these years provided a counter to both the mainstream views of the Civil Rights movement as well as what would become Black Power. As Kevin M. Schultz writes, "Baldwin possessed the hope of Martin Luther King, Jr., but the threat of Malcolm X." ${ }^{20}$ This combination proved particularly powerful as Baldwin increasingly brought arguments rooted in economics into his debates in the 1960s. ${ }^{21}$

The Baldwin-Buckley debate represents an early moment of the culture war between the demands of civil rights social justice movements and the so-called "white backlash" or states' rights advocates who bristled against anti-racist federal intervention. ${ }^{22}$ Narrowly framed as "white backlash," the concept obscures the deep fissures of American history as it implies a black provocation against a white presence innocent of past and present crimes. Through today, culture war debates against the claims of social justice activists continue to evoke a reclamation of innocence through a limited range of historical evidence-egregiously on display in recent debates surrounding Texas high school textbooks. ${ }^{23}$ The Cambridge debate between Baldwin and Buckley underscored the two very different sets of language and knowledge that anchor the culture war. Mobilized in reaction to the demands of the Civil Rights movement, an ethos inherited through the historical experience of people of European descent comprised the range of encounters with the New World, the West, the Other, the enslaved, the Alien, the savage, and the black. By ethos, I mean an argument or vision of the world based on authority, with the latter woven through the "virtues most valued by the culture to and for which one speaks." ${ }^{4}$ The dominant American attitude constructed through the modern processes of slavery, settler colonialism, and patriarchy shaped a vision of the world that translated the violence required to ethnically cleanse Native Americans from their land, enslave people of African descent, and objectify women as the property of men into a system experienced as a naturally ordered 
and righteous civilization led by white men. The notion of civilization melded together the idea of "progress" into a culture developed through these experiences and structures that helped Americans navigate and define their history and identity. ${ }^{25}$ The Baldwin-Buckley debate provides a snapshot of the collision of these ideals, while weaving a systemic tapestry that outlines the relationship of power to language and the possession of history. While Buckley's ethos used the "progress"-laden language and history of "Western Civilization" to defend his position, Baldwin's approach foregrounded the Black Radical Tradition's subaltern position of the enslaved, the oppressed peoples written out of history. This confrontation between a system of knowledge developed through the processes of colonialism and slavery-i.e., modernity-and its contestation by those caught within its tendrils represents the stakes of the 1965 debate at Cambridge, as well as the anchoring precepts of the post-1960s culture war. ${ }^{26}$ The key to this struggle was the possession of the meanings of history.

Commenting in the last decade of his life on the nature of history, Baldwin discussed the inability of people to escape "history and the effects of history": ${ }^{27}$

I have been living with those questions for a long time. You see, the trouble I am having right now is with the word itself. History means one thing in a European head. It actually means something else in an American head, and yet again something else in a black man's head. To leave it at that is enough for openness. I am not sure any longer what the word means. Especially as the white world now is calling on what it calls history to justify its dilemma without having the remotest sense of how they got to where they are. In spite of their adulation of history ... Because if history means something, it means that you have learned something from it. If you haven't then the word has got to be changed. History in England, or France, or Germany, or indeed in Europe is now meant as an enormous cloak to cover past crimes and errors and present danger and despair. In short, it has become a useless concept. Except that it can be used as a stick to beat the people without history, like myself, over the head. That worked as long as I believed that you had history and I did not. And now that it is clear that that is not so, another kind of dilemma, another kind of confrontation, begins. Perhaps history has got to be born for the first time. It is certainly true that all the identities coming out of history with a capital $\mathrm{H}$ are proven to be false, to be bankrupt... And in terms of America, the Americans are even more abject than the Europeans who are stifling among their artefacts, their icons, which they call history. The Americans have never even heard of history, they still believe that legend created about the Far West, and cowboys and Indians, and cops and robbers, and black and white, and good and evil ... If the Europeans are afflicted by history, Americans are afflicted by innocence. [my emphasis] ${ }^{28}$

When Baldwin reflected on whether or not one could escape history or its effects, he identified an important component: analyzing the present and the past from within the language and knowledge inherited from a past draped in oppression. Baldwin identifies an important bottleneck that impedes the ability to articulate and reconcile the crimes of the past and their bearing on the present. One needed power to control the circulation of knowledge, which, in turn, helps frame 
the boundaries of debate. These boundaries establish the setting for American innocence-and the disavowal of its violent legacy. ${ }^{29}$ Indeed, specific to this power is the ability to silence one's history if it reflects an inconvenience to contemporary policies, or the necessity for the construction of a remembered past in light of policies aimed toward discrediting oppressed people's claims in the present. This struggle between forgetting and remembering becomes especially relevant when one is constantly beaten over the head by the very forces of institutionally remembered history. Forgetting or remembering help buttress contemporary rhetoric and policies, ultimately providing shape to material or economic processes while cultivating forms of oppression and privilege. Violent oppression, historically, allows for the disciplining of this knowledge, leading to the ability to frame both contemporary reality and the historical record. This violence, as Greg Grandin suggestsparaphrasing Elaine Scarry-both performed and performs a "function," whereby acts cloaked in rhetoric subsume violence into prerequisite norms through which different groups interact historically. ${ }^{30}$ The power to dominate generally favors those with history, literally establishing a norm that structures the violent antagonisms toward those, as Baldwin asserts, "without history." ${ }^{11}$ Remembering particular stories about the past, then, rhetorically extends the past into the present, shifting memories and impulses into conceptual, historically vindicated relationships with the current moment. Toni Morrison's thoughts on this dynamic are again relevant when she asserts an American self is "not history-less, but historical; not damned, but innocent; not a blind accident of evolution, but a progressive fulfillment of destiny." ${ }^{2}$ In short, the recurring trope of innocence is crucial for defining the American self, as its very identity is wrapped in the bloodied layers of crimes against humanity related to settler colonialism and slavery.

To profess innocence amidst a history of brutal racial antagonism, a certain level of performance is needed. Paraphrasing William Faulkner, Baldwin once asserted, "history is not the past, it's the present. One may even make an argument, in a couple of more weeks, that history is never the past, that everyone is always acting out history." ${ }^{33}$ Baldwin suggests here that real history is performed every day by people, who act out their historically inherited patterns of relations. We might call these performances "historical projections," conglomerations of inherited rhetoric, discourse, ideology, gestures, and the results of material power-mobilized and regulated through one's position in society. More precisely, these interactions reflect Baldwin's concept of the balance of power between those possessing history and those supposedly lacking history. Historical projections in practice help facilitate the dominant common sense and historical calculation that directs society's traffic through well-rehearsed paths within familiar stories of normalized prejudice. Performance and adherence to these constructed traditions in everyday life creates links to the past, with conflicts often resulting when an act of remembering questions the dominant narrative of the past and present. A culture war generally ensues in the wake of such trespass.

These culture war struggles over the possession of history take us back to the relevance of the longue durée. A narrowly remembered history-encompassing 
decades, for example-too often eludes the longue durée processes that haunt sets of centuries-old norms, such as racism, sexism, and homophobia. Absent the larger context of history, the narrow conception leads to an ostensibly "clean slate" for future arguments to operate free from their historical connection to the "whole longue durée of racial dictatorship since the conquest." ${ }^{4}$ The unpleasant past is quarantined like a virus, allowing the nationalist trope of "innocence" to be redeemed. Exceptionalism amidst innocence disavows the violent past's contribution to the present while placing a "silence" around ongoing, centuries-old practices expressed through reformed language absent of explicit racism. ${ }^{35}$ The performance of disavowal or silencing mobilizes ideas of "progress" to blanket the present. It is here, in "progress," where the very sense of "innocence" Baldwin and Morrison suggest afflicts the American idea of history obscures the violence of settler colonialism and slavery that contributed to the American dream. Performances and gestures project these values of progress and innocence in times of conflict-particularly in the 1960s. The Baldwin and Buckley debate epitomizes these sets of performances, where a reconstruction and struggle over the possession of the past actively mobilizes deeply ingrained ideas linked to the centuriesold processes, while the reaction to the critique of the present and its past legacies equates to the undermining or destruction of civilization.

This article tells a story about this process, when moments are filled with historical projections, haunting the present with the ideas and performances of the past. In particular, it focuses on a moment in U.S. history when American innocence, as Baldwin describes it, collapsed amidst a decade of social -and later, economicupheaval. As the nation attempted to come to terms with its legacy of settler colonialism and slavery through the mediation of the 1950s and 1960s Civil Rights movement and the Vietnam War, rather than confronting these ghosts, a retrenchment of privilege emerged that guarded the innocence of those with history against the criticism of those "without history." An important component of this reaction included a wholly systemic shift in formal processes of racial exclusion, the deregulation of Jim Crow laws-which helped anticipate the flood of deregulation that accompanied the rise of neoliberalism in the 1970s and 1980s. With overt laws against African Americans deregulated through civil rights legislation, a new language emerged to buttress the old structural contours of white privilege formerly held in place by Jim Crow laws. The southern resistance to desegregation laws eventually led to a colorblind argument for exclusion based on the rights of property. These pro-segregationist maneuvers intersected with Buckley's political focal point of individual rights, which now emerged as the entity most aggrieved from the policies of an interventionist government trying to build social equality. We may read the Baldwin and Buckley debate in 1965 as an early battle of this culture war.

At Cambridge, Baldwin represented the descendants of American ex-slaves, a status in 1965 that bore the racial antagonism represented by American history and its obsession with anti-blackness. Baldwin's work-both fiction, but especially non-fiction-examined these processes throughout the mid-twentieth century, 
addressing the ongoing anti-black antagonisms that Saidiya Hartman calls the "afterlife of slavery." 36 The material and cultural aftermath of the colonial era and the nation's founding utilized the ideas of enlightenment progress to form a contradictory coexistence between, on the one hand, the recognition of the "rights of man," and, on the other, a specificity of these rights so that they did not apply to those nonwhites who were colonized or enslaved. The strands of anti-blackness compose and strengthen frameworks that justify "progress," the frontier, Manifest Destiny, and "the white man's burden," relaying a tale of innocence amidst the attempts to perfume the violated bodies strewn across North America, caught in the aftermath of colonization and slavery. Policing this line, often in light of miscegenation fears, mobilizes not only the state apparatuses but the public as a white whole via civil society: the protection and defense of the common, where conscripts identifying as white mobilize against black intrusions. As Wilderson suggests, these conscripts are "deputized," filled with an arsenal of historical projections pursued through the faith of progress. ${ }^{37}$ The insistent anti-black attitudes emanating from an identity sealed through this historical convergence provide a crucial pivot that facilitates the cultural understandings of gender, sexuality, class, and the geographic mapping of civil society-including whose voices are heard, and whose are silenced in the name of guilt and innocence.

Buckley, a descendant from Ireland, represented the quintessential white ethnic. This identity, revived in the 1970s after a brief pause during the postSecond World War years of white ethnic assimilation into suburban America, largely emerged as a response to the ethnic pride movements initiated with the Civil Rights/Black Power movements. ${ }^{38}$ Buckley articulated an important reframing of the "race" debate in this era when "racial" arguments increasingly fell out of respectable debate. Beginning publicly in the 1950s in his journal, The National Review, Buckley's attacks against the Civil Rights movement stressed the supposed cultural deficiencies of African Americans when compared to other ethnic Americans, such as the Irish, Italians, or Jews. ${ }^{39}$ This shift in language from racial science to ideas of culture formed a core component of what would emerge in the 1970s as colorblindness. The meeting of Baldwin and Buckley in 1965 represents an important clash within the longue durée of U.S. history, when a descendant of slaves mobilized memory surrounding the history of the black American while the white ethnic attempted to deflect the criticisms by mobilizing the ghostshistorical projections-long haunting and facilitating the anti-black contours of the republic.

The broadcast announcer, St John-Stevas, described Baldwin as the "star of the evening" as the author rose and ventured through the crowded Union to the podium amidst tumultuous applause. Framed in a sea of white British faces, with a few black Britons, Baldwin initially responded to the question of the American dream and its relationship to the Negro by calmly posited that the overarching, "deeper" question depended on "one's point of view," "on where you find yourself in the world, what your sense of reality is. That is, it depends on assumptions we hold so deeply as to be scarcely aware of them." 40 Baldwin outlined this 
notion by describing the dynamics of white interpretations of black resistance to racial oppression. For whites, this resistance appeared as an irrational attack on "the system to which [the white man] owes his entire identity." ${ }^{1}$ The status quo of the social structure-from cultural to economic-fostered a white identity through an inverse relationship with blacks, where subjugation by whites occurred through a "naturally" established social disposition. This binary of white freedom and black enslavement resulted in the violent policing of the meaning of whiteness to preserve the status quo, to preserve white identity. Years later, Baldwin further explained the intricacies of this relationship between whiteness and blackness: whiteness was a set of attitudes that permeated the system of oppression, whereas blackness was the condition created by these antagonistic beliefs toward black bodies. ${ }^{42}$ This situation left resistance by black people to be seen as an affront toward, or a revolutionary overthrow of, the system to which whiteness gives both spiritual and material meaning. From the lack of deference to breaching color lines to all-out insurrection, a society premised on whiteness viewed black agency as turning civilization on its head. Finally, Baldwin contextualized blackness in the economy-the "expense" of this system-noting the free labor blacks provided to build the ports, railroads, harbors, and other economic features that aided industrialization and the accumulation of capital.

The violent subjugation of people of African descent as property-and after emancipation, as cheap labor-intimately connected the economy to the sets of meanings attached to skin tone, forming the ontological triggers for American anti-black racism. This relationship performed another role for those not benefitting from the accumulation of capital. Describing the minds of poor whites, Baldwin outlined their frame of reference to his Cambridge audience: "they have been raised to believe, and by now they helplessly believe, that no matter how terrible some of their lives may be and no matter what disaster overtakes them, there is one consolation like a heavenly revelation-at least they are not black." 43 An investment in anti-blackness, then, is the reward for white acquiescence to the American dream. In this sense, monetary value binds itself to a racially coded binary, most notably observed in the greatest postwar asset the majority of white Americans possessed: federally subsidized housing in the white spaces of suburbia. ${ }^{44}$ Moving to the present, Baldwin announced to the audience:

What we are not facing is the results of what we've done... What is crucial here is that unless we can manage to establish some kind of dialogue between those people whom I pretend have paid for the American dream, and those other people who have not achieved it, we will be in terrible trouble.

Here we see Baldwin's notion of the operation of history at work, insisting that those living in the present recognize the outcome of this centuries-old paradox anchoring the American dream. This recognition demands, however, an admission that the American dream embodied a white imagined space and existence, and that it was created through an ethos built upon the brutality of slavery and the 
exclusion of African Americans from the protections of civil society. ${ }^{45}$ The inability to grasp this history would spur the sort of crisis of identity Baldwin spoke of to Nikki Giovanni. Adding an ominous epilogue, Baldwin summed up:

until the moment comes, when we, the Americans, we the American people, are able to accept the fact, that I have to accept, for example, that my ancestors are both white and black, that on that continent we are trying to forge a new identity, for which we need each other. That I'm not a ward of America; I'm not an object of missionary charity. I am one of the people who built the country. Until this moment, there is scarcely any hope for the American dream, because the people who are denied the participation in it, by their very presence, will wreck it. And if that happens, it's a very grave moment for the West. Thank you.

\section{A standing ovation in the Cambridge Union hall followed.}

More subdued applause greeted Buckley's arrival, unlike Baldwin's raucous reception. Buckley began with a solemn appraisal of Baldwin's "indictments," with his rebuttal immediately underlining many of the stakes outlined by Baldwin's theorization of the American dream. Through his well-known eloquence, speaking calculatedly and with aloofness, Buckley's argument literally performed the model of oppression-mobilizing historical projections-outlined by Baldwin. Buckley began by normalizing the field of objectivity as a strict domain of "white rationalism" in an attempt to disqualify Baldwin's testimony. Performing an inverted form of Baldwin's claim about what one's "sense of reality is" and their deeply held assumptions, Buckley asserted:

It is quite impossible in my judgment to deal with the indictment of Mr. Baldwin unless one is prepared to deal with him as a white man, unless one is prepared to say to him that the fact that your skin is black is utterly irrelevant to the arguments that you raise. The fact that you sit here as is [sic] your rhetorical device, and lay the entire weight of the Negro ordeal on your own shoulders, is irrelevant to the argument that we are here to discuss.

Underlining the dichotomy between "those with history" and "those without history," Buckley demanded an erasure of Baldwin's blackness-his historyfrom the debate. The question at hand, according to Buckley, could not be judged objectively by someone who is black. With the loss of an unapologetic white supremacy, the demand for colorblindness wrapped in white normativity stressed Baldwin's bias as a black man-while underlining Buckley's innocence as a mere rational white man attempting to make sense of the era's upheavals. We may associate this reform, later embraced by neoliberalism, as a continuation of modernity's "scientific" objectivity, so crucial for the engineering of the dreams and truth statements of Europeans and white Americans. ${ }^{46}$ The ability to be objective, especially for white Americans, established itself through a measurement of humanity that set people of African descent as the savage "race" furthest away from the "superiority" of rational European "stock." Buckley's objectivity, 
or arguments grounded in the normal capacity of whiteness to judge things exterior to it, offered a reassuring balm-a pledge of innocence-for those participating in the brutality toward nonwhites in the name of maintaining Western modernity and civilization. Buckley's pronouncements mobilized the historical projections still circulating in the mid-1960s which mimic this logic: the socially dead-enslaved, or descendants of enslaved Africans-cannot speak their case as they are without history. This rhetorical shift for Buckley, moreover, provides insight into the evolution of colorblindness from its overtly racist origins. Indeed, eight years before the 1965 debate Buckley rigorously defended the resistance of southern segregationists against desegregation: "the White community is so entitled [to discriminate] because it is, for the time being, the advanced race." ${ }^{37}$ Colorblindness removed the explicit racial markers from language criticizing the Civil Rights movement.

The attempt to undermine Baldwin's credibility spoke to mid-1960s anxieties about whiteness and blackness and the historically reflexive white fears of the formerly subjugated, now speaking back. These anxieties, moreover, were tied to the dissolution of other older ideas constructed to imply the innocence of white participation in anti-blackness, notably connected to plantation conceptions of Sambothe passive Negro, whose child-like behavior needed direction and guidance-and notions of self-rule. ${ }^{48}$ Notions of self-rule are related to ideas surrounding the African American as socially dead, outside civil societies' boundaries of decency and security. At the debate in 1965, the logic of self-rule emerged through an ad hominem attack aimed at Baldwin. Buckley suggested that "He [Baldwin] didn't, in writing that book [The Fire Next Time], speak with British accents that he used exclusively tonight"- thus painting Baldwin with the caricature of Zip Coon, the awkwardly free black who, despite trying, can never speak, act, or think like a white man ${ }^{49}$ In the same sentence, Buckley also charged Baldwin with threatening "America with the necessity for us to jettison our entire civilization." Again, for Buckley, the removal of the oppressive conditions connected to policing blackness would turn the ethos of white America, specifically its putative "progress" narrative of innocence, on its head..$^{50}$

In a full performance of the post-Civil Rights movement's white defense of privilege, Buckley inverted the power dynamics between whites and blacks. Bestowing a particular power on Baldwin in the presentation of his case, Buckley presented himself as unfairly matched - not against the intellect of Baldwin, but against a presumed social power Baldwin held over him, a mere white man. "Tonight," Buckley announced, he was "going to speak to [Baldwin] without any reference whatever to those surrounding protections which [he was] used to in virtue of the fact that [he is] a Negro." This performance of powerlessness focused on a narrow moment of the present that stipulated a level of rhetorical power on behalf of blackness despite centuries of white supremacy and anti-blackness. Rhetorically excluding the longue durée history between people of European descent and those of African descent, Buckley attempted to gain allies in the Cambridge hall who might feel uncomfortable with increased public criticism of deep traditions that have now 
been condemned as racist. Lipsitz calls this type of situation a "manifestation of privilege masquerading as powerlessness." 51 According to Buckley, Baldwin's blackness simultaneously disqualified him from engagement in civil society to make his own arguments, while at the same time Baldwin's blackness was pronounced as an unfair power advantage over the innocent, white ethnic Buckley. In minutes, centuries of white supremacy and systemic anti-blackness dissolved; race as an identity was suddenly denounced as an unfair rhetorical device to gain favor or power. Indeed, Buckley's performance is an early moment of colorblindness where, as Singh notes, "Race now means racism, especially when it is used to define or defend the interests of a minority community." 52

Buckley's parries illustrated more than merely the modern fear of the enslaved striking back at the master. More importantly for the next decade's economic restructuring, these discursive strategies were employed to reconceptualize the operation of power by historically erasing centuries of white privilege after a decade of embarrassing scenes transmitted globally of white brutality against blacks who were seeking the protections of the Constitution. In his assessment of the unfairness of Baldwin's blackness, Buckley helped to anchor a conceptualization of 350 years of white antagonism toward blacks as a process conceived of as reciprocal, with each "side" suggested to have equal ability to deliver "damage" to the other. In short, a system of "race relations," which "assumes that racial prejudice arises out of a natural antipathy between groups on the basis of difference," rather than a system of "racial oppression," which "locates the source of the problem within the structure of society," where a "system of domination . . . entails major political and economic institutions, including the state itself." 53 As a relationship decontextualized from history, one could innocently frame any support for African-American equality as promoting an unfair privilege against whites, a familiar binary in reverse formed through whiteness as an ethos and blackness as a condition-now inverted at the height of the civil rights era when overt white supremacy had lost its respectability. Often misidentified as suddenly appearing in U.S. history, the so-called "white backlash" countered the growing chorus of 1960 s social movements that questioned the basis of "civilization," by positing a renewal in white innocence.

Alongside the rewriting of history, Buckley also deflected the criticisms of African Americans away from notions of structural racism. In attacking Baldwin's argument, Buckley dismissed the connection between capital accumulation and enslaved or Jim Crow disciplined black labor. A primary tool for Buckley's defense of the status quo lay in the arguments that underpinned a book he suggested the students read to fully understand the situation in America: Nathan Glazer and Daniel P. Moynihan's Beyond the Melting Pot: The Negroes, Puerto Ricans, Jews, Italians, and Irish of New York City (1963). ${ }^{54}$ Published the same year as Baldwin's The Fire Next Time, Beyond the Melting Pot embodies what historian Matthew Frye Jacobson calls "an inaugurating text" of the culture wars. ${ }^{55}$ "My great grandparents worked too, presumably yours worked also," Buckley innocently proclaimed, reciting what would become a familiar white retort to 
Affirmative Action. ${ }^{56}$ In explaining the "complicated" nature of the racial problem in the U.S., Buckley suggested that the issue existing in America was individual discrimination against blacks, not institutional racism; a problem for reform, not for radical solution.

Buckley's use of Moynihan, co-author of Beyond the Melting Pot, is noteworthy in the fact that the latter was instrumental in developing white liberal, and later conservative, responses to black critiques of institutional racism, beginning with The Moynihan Report (1965), his contribution to President Johnson's commencement speech at Howard in 1965, and his later memo to President Nixon in 1970 suggesting that the "issue of race could benefit from a period of benign neglect. The subject has been too much talked about." ${ }^{\prime \prime 7}$ The other co-author, Glazer, later wrote Affirmative Discrimination in 1975 where he asserted that Affirmative Action policies were unfair for whites, who were innocent of the crimes of their ancestors. ${ }^{58}$ Working from this intellectual tradition, Buckley's second suggestion during the debate was to assert that a primary "failure of the Negro community itself [was its inability] to make certain exertions which were made by other minority groups during the American experience." Noting the absence of the "particular energy ... so noticeable in the Jewish community and to a certain, and lesser, extent, in the Italian and Irish community," Buckley asserted, "We should focus on the necessity to animate this particular energy" in African Americans. In short, they should be encouraged to develop an ethos-a favorite word for Buckley when describing this situation throughout his television series, Firing Line. For example, on a 1967 episode of Firing Line when Buckley interviewed Nat Hentoff about Black Power, Buckley questioned whether access to power was the only thing holding back African Americans: ${ }^{59}$

Well, one of the reasons that I am perhaps as baffled as other people in trying to understand your critique, and that of so many other people, is I am never quite sure whether Black Power means that the desiratum [sic] is simply the use of a lever, with a maximmization $[s i c]$ of the lever inferred, or whether there is built into that some sort of concept; for instance, there is Black Power in Ghana, isn't there-not a hell of a lot of progress from your standards or mine-so, pure political power isn't of itself enough. It is political power united with certain concepts, a certain ethos, that you and I feel we want to push. We hear from somebody like James Baldwin who says that the only thing the white man has that the Negro should want is power-meaning that he explicitly disdains the criteria, the value system of the white community. ${ }^{60}$

Buckley's use of the concept of ethos underscored a perceived lack of cultural ability to adapt to mainstream white society, what previous eras had simply termed white superiority toward black inferiority. This new language amidst the changing political landscape of the civil rights era was necessary to keep alive the sentiments of anti-blackness through colorblind assertions via culture and ethos. A crucial element in this shift included the increasingly popular trend among critics of the Civil Rights and Black Power movements to compare the historical experiences of African Americans to those of white ethnics-a task pioneered by Glazer and 
Moynihan, and championed by Buckley. As Jacobson notes, “The historical weight of incorporation by conquest or by slavery, for instance, was of little account in this model, as all groups could expect to proceed along roughly the same lines of acceptance, mobility, and success as had the great waves of immigrants from Europe beginning in the 1840s." ${ }^{\prime}$

By contrasting the differences between African Americans and white ethnic Americans, Buckley helped to outline the rhetorical contours of Martin Barker's notion of the "new racism," in which theories of race are concealed in order to "provide form and structure to people's experiences and reactions, without displaying itself as a whole theory with big and dangerous implications." 62 Without explicitly saying so, Barker suggests historical projections play a role in the new racism: older, scientific-biological notions of race are concealed in a language of culture. The notion of culture carries with it the baggage surrounding ideas of civilization, setting parameters where culture discursively links up to older notions of science and biology at the same time that it obscures the discredited assumptions of racial superiority through language describing "a 'way of life"'-with the latter judged from the dominant cultural perspective. ${ }^{63}$ As the authors of The Empire Strikes Back: Race and Racism in 70s Britain assert, "Once the argument has been couched in terms of 'alien cultures', common-sense racism can be relied upon to provide the missing inflexions." 64 Rather than having racial matters weighted in biology and science, the dominant issue is "the insurmountability of cultural differences, a racism which, at first sight, does not postulate the superiority of certain groups or peoples in relation to others but 'only' the harmfulness of abolishing frontiers, the incompatibility of life-styles and traditions." ${ }^{65}$

For Buckley and many of his successors, culture replaced the explicit racial arguments that justified the conditions of African Americans, relieving white society of complicity in fostering racial antagonism. From a position of innocence, Buckley's cultural approach ventured into the sociological territory inhabited by Glazer and Moynihan, where a technocratic and "unbiased" study denoted the range of deficiencies allotted to African Americans. In Nobody Knows My Name (1961), Baldwin asserted:

One of the reasons we are so fond of sociological reports and research and investigational committees is because they hide something. As long as we can deal with the Negro as a kind of statistic, as something to be manipulated, something to be fled from, or something to be given something to, there is something we can avoid, and what we can avoid is what he really, really means to us. The question that still ends these discussions is an extraordinary question: Would you let your sister marry one?66

This combination of statistical investigation and the sexualization of the socalled "Negro problem" was mobilized alongside another set of self-rule tropes near the end of Buckley's speech. Adding statistics from Beyond the Melting Pot to underline the inferior ethos of African Americans, Buckley confidently asserted the cultural distance between blacks and whites (and, thus, the justification for 
discrimination): "Fourteen times as many people in New York City born of Negros are illegitimate as of the whites." Building on this conception of black deviancy, Buckley then connected the biological deviance of blacks with the ignorance of poor whites in response to one student's heckle demanding that blacks be able to vote in Mississippi: “The problem in Mississippi isn't that too few Negroes can vote; it's that too many whites can." This remark itself conveniently laid the blame for individual racism on the poor and ignorant, simultaneously erasing the origins of institutional racism as well as creating a rhetorical bridge between black inferiority and poor white ignorance. Buckley followed up the question by paraphrasing the conservative black thinker Booker T. Washington, in suggesting that mere voting rights or holding public office were not enough: "but that they be prepared to hold public office. Not that they vote, but they be prepared to vote . . It is much more complicated, sir, than simply just the question of giving them the vote."

For Buckley, the obstacle facing African Americans was the white supremacist notion inherent in questioning self-rule for blacks (and worldwide for other nonwhites) and self-rule's contingency on the adoption of white Western values or ethos. According to Buckley's logic, self-rule was an impossibility for African Americans, as he embraced the colorblind, cultural pathology of Glazer and Moynihan's assessment of the failure of African Americans to assimilate, like white ethnics, into U.S. society. White innocence, then, succumbs to the burden of guiding African Americans. These "new" ideas offered a replacement for the blunt language used by Buckley in an August 1957 issue of National Review, where he used the trope of self-rule in describing the situation facing African Americans in the South. Though a bit less subtle, Buckley's original thoughts stressing notions of progress and innocence in the matter of civil rights reveal the connections between race, economics, and political power:

Reasonable limitations upon the vote are not exclusively the recommendations of tyrants or oligarchists (was Jefferson either?). The problem in the South is not how to get the vote for the Negro, but how to equip the Negro-and a great many Whites-to cast an enlightened and responsible vote ... The South confronts one grave moral challenge. It must not exploit the fact of Negro backwardness to preserve the Negro as a servile class. It is tempting and convenient to block the progress of a minority whose services, as menials, are economically useful ... So long as it [the South] is merely asserting the right to impose superior mores for whatever period it takes to effect a genuine cultural equality between the races, and so long as it does so by humane and charitable means, the South is in step with civilization, as is the Congress that permits it to function. ${ }^{67}$

The discourses of civilization, reason, and progress, so essential to justifying processes of American history-from slavery to ethnic cleansing to the restriction of women's rights-are utilized by Buckley here to save the South from criticism of its own "civilization." His earnest defense and attempted redemption of the South rests upon centuries of anti-black oppression, with violence sculpting black enslavement in tandem with the ideas and processes of white freedom. The assertion of 
"Negro backwardness" easily fit into its antithesis of white "superior mores," justifying Buckley's logic of inequality of power, delaying "genuine cultural equality," and helping shape the dynamic of individualizing structurally racist institutions. By the 1960s, Buckley had replaced his explicit racism with a more polite colorblind language aimed toward justifying racial inequality. Consequently, reform by the late 1960s entered structural discourse rather than the actual structural relationships that might finally end the rationale for slavery, and the ontology of anti-blackness.

For Buckley, American history leading up to the 1965 debate found "reasonable" precedents in the anti-black policies of the colonists and founders, and later, the segregationists who appeared to be unfairly tarnished as "tyrants" as they resisted desegregation in the 1950s and 1960s. His history operated from the vantage point of an American civilization built despite the presence of "Negro backwardness," a condition emphasizing the rugged individualism of white ethnics such as himself. At the same time, Buckley demanded the renewal of American innocence in the years since Brown vs. Board of Education, despite the world having witnessed the brutally violent reaction against black Americans seeking constitutional protection. Culturally, this reaction mimicked the mission statement of the National Review, first published a year after Brown vs. Board, which stated: "[the National Review] stands athwart history, yelling Stop, at a time when no one is inclined to do so, or to have much patience with those who so urge it." ${ }^{68}$ As a white ethnic "possessing history," Buckley's normalized position as a white male gave a powerful momentum to his statements. From his unveiled racist National Review sentiments to a more colorblind set of parries and strikes during his debate with Baldwin, Buckley's statements embody how historical projections operate. Framed from a position of innocence, the primary element keeping African Americans from enjoying the civil rights of white Americans was their assumed inability, their unpreparedness to participate in American institutions such as voting and holding office. In laying the blame on implied ignorance, systemic components such as the institutional racism deeply woven into the American social fabric fail to arise. In the face of charges from a historically marginalized group, this projection of both an ideally innocent history and the implied assertion of black inferiority via nuanced suggestions of ignorance personifies the dynamics of historical projection. Indeed, Buckley's gestures and language at Cambridge in 1965 anticipated the new post-civil rights bulwark of whites and the status quo against further critiques of institutional racism.

This performance of a non-overtly racist defense against the criticisms of the American dream in 1965 characterized the cultural shift that responded to the overall deregulation of civil rights in the U.S. Indeed, the deregulation of Jim Crow laws and exclusionary housing policies anticipated the deregulatory program involved in the replacement of Jim Crow/Keynesian economics. If Jim Crow laws created a strict segregation of employment opportunities on the basis of anti-black cultural logic, once removed the logic would remain, though now wrapped in a colorblind ideology. Economically, the post-civil rights era saw 
the welfare state, which primarily benefitted white male Americans, replaced with the more laissez-faire, privatized system of neoliberalism in the 1970s and 1980s-effectively dismantling the welfare state at the same moment that African Americans gained full access to it via 1960s civil rights legislation. All the wealth and economic opportunities accrued via the racist Jim Crow/Keynesian system now hid behind the veil of neoliberal colorblindness-innocently contributing to white Americans who were lucky enough to benefit from the postwar boom. Along with the absence of reparations for slavery and for the Jim Crow segregation years, nothing addressed the ongoing ontological features that inhabited institutional racism after the 1960s-leaving the reason for slavery and Jim Crow untouched. Working through the longue durée normalcy of black inferiority and exclusion from the rights of civil society, these reforms deregulated the legislature and the now-outdated language that supposed an unabashed white supremacy-or Buckley's thinly veiled "superior mores." Rather than explicit language, such as the "Negro problem," the path was cleared for a new language, such as the "urban problem," which re-articulated the deep sentiments of anti-blackness connected to Jim Crow/Keynesian racial language. Divorced from their overtly racist origins, the new colorblind terms continued to mark their targets. Rather than viewed as an inconsistency in the evolution of the American dream unfolding across the centuries, the new language that coincided with civil rights legislation not only continued to regenerate the larger impulses born of slavery, but also provided the cultural-economic system with a new veneer, a new innocence draped around the celebrated narrative of "progress" woven through 1960s civil rights legislation.

Baldwin continued to work through these issues at the dawn of the 1970s, publishing No Name in the Street (1972), the delayed follow-up to The Fire Next Time. No Name in the Street reflected both a contemporary assessment adorned in pessimism as well as a prophecy regarding the inability of U.S. society to come to terms with its legacies of modernity, particularly its bond with slavery and antiblackness. ${ }^{69}$ Reminiscing about the previous decade's civil rights activism and dialogue on race, Baldwin noted the ongoing haunting of America's past. Without a thorough discussion of the vast cultural arteries of anti-blackness coursing through the body of the nation-state, closure would be impossible for the U.S. Throughout his memoir of the 1960s, Baldwin returned to the paradox of the American dream and its relationship to history:

[William Faulkner] is seeking to exorcise a history which is also a curse. He wants the old order which came into existence through unchecked greed and wanton murder, to redeem itself without further bloodshed-without, that is, any further menacing itself-and without coercion. This, old orders never do, less because they would not than because they cannot. They cannot because they have always existed in relation to a force which they have had to subdue. This subjugation is the key to their identity and the triumph and justification of their history, and it is also on this continued subjugation that their material well-being depends. ${ }^{70}$ 
The continued mobilization of anti-blackness via cultural pathology allowed "pathology" to emerge as a new euphemism for race. As the 1970s dawned, and the explicit markers of racial designation were replaced by cultural pathology, a new baseline of objectivity emerged, innocent of the legacies of slavery. Noting the difficulty of dismantling the new colorblind racism in the post-civil rights U.S., in 1980 Baldwin remarked, "another kind of dilemma, another kind of confrontation, begins." ${ }^{\prime 1}$ That dilemma essentially involved wrestling with the ghosts of history guiding white privilege, which, in the wake of civil rights legislation, reset the playing field of the American dream, its innocence renewed for future generations.

\section{Notes}

1 Toni Morrison, Playing in the Dark: Whiteness and the Literary Imagination (New York, Vintage, 1992), pp. 44-5.

2 See James Patterson, The Eve of Destruction: How 1965 Transformed America (New York, Basic Books, 2012).

3 Ibid., p. 18.

4 For anti-blackness, see Jared Sexton, Amalgamation Schemes: Antiblackness and the Critique of Multiracialism (Minneapolis, MN, University of Minnesota Press, 2008); Frank B. Wilderson III, Red, White \& Black: Cinema and the Structure of U.S. Antagonisms (Durham, N.C., Duke University Press, 2010); Morrison, Playing in the Dark, p. 44.

5 See Ira Katznelson, When Affirmative Action Was White: An Untold History of Racial Inequality in Twentieth-Century America (New York, W.W. Norton, 2005); David M. P. Freund, Colored Property: State Policy \& White Racial Politics in Suburban America (Chicago, University of Chicago Press, 2007).

6 James Baldwin and Nikki Giovanni, A Dialogue (Philadelphia, PA, J.B. Lippincott, 1973), pp. 19-20, 70-1, 88-9.

7 See Melvin L. Oliver and Thomas M. Shapiro, Black Wealth, White Wealth: A New Perspective on Racial Inequality (New York, Routledge, 2006).

8 William F. Buckley, Jr., "Our Mission Statement," National Review, 19 November 1955, http://www.nationalreview.com/article/223549/our-mission-statement-william-fbuckley-jr (accessed 8 September 2016).

9 Debate: Baldwin vs. Buckley, National Educational Television Network, February 1965. See https://www.youtube.com/watch? $\mathrm{v}=\mathrm{oFeoS41xe7w}$ (accessed 8 September 2016). The transcription of the debate appeared in the New York Times. However, the transcription was most likely the written speeches, whereas both Baldwin and Buckley deviated substantially from their prepared statements. "The American Dream and the American Negro," New York Times, 7 May 1965, SM32. All citations of the debate are from the actual debate, and not from the printed speeches from the New York Times.

10 See W. J. Weatherby, James Baldwin: Artist on Fire (New York, Donald I. Fine, 1989), pp.273-5; David Leeming, James Baldwin: A Biography (New York, Alfred A. Knopf, 1994), pp. 244-5; Kevin M. Schultz, Buckley and Mailer: The Difficult Friendship That Shaped the Sixties (New York, W.W. Norton, 2015). 
11 See Stephen Steinberg, Turning Back: The Retreat from Racial Justice in American Thought and Policy (Boston, MA, Beacon Press, 1995).

12 For work on the Annales school, see Peter Burke, The French Historical Revolution: The Annales School 1929-2014 (Stanford, CA, Stanford University Press, 2nd ed., 2015); Lynn Hunt, "French History in the Last Twenty Years: The Rise and Fall of the Annales Paradigm," Journal of Contemporary History, (1986), pp.209-24; Allan Megill, "Coherence and Incoherence in Historical Studies: From the Annales School to the New Cultural History," New Literary History, 35:2 (2004), pp. 207-31.

13 Fernand Braudel, On History, trans. Sarah Matthews (Chicago, University of Chicago Press, 1980), p. 32.

14 For the Black Radical Tradition, see Cedric J. Robinson, Black Marxism: The Making of the Black Radical Tradition (Chapel Hill, N.C., University of North Carolina Press, 2000). Exploding to life from the violence encountered and resisted by the first group of enslaved Africans to the New World, Cedric Robinson describes the Black Radical Tradition as "an accretion, over generations, of collective intelligence gathered from struggle. In the daily encounters and petty resistances to domination, slaves had acquired a sense of the calculus of oppression as well as its overt organization and instrumentation" (p. xxx). A genealogy of resistance rooted in slavery and maroon communities, and later post-emancipation forms of de jure and de facto segregation and resistance, informed this evolving tradition which adapted to the changing process of racist oppression rooted in settler colonialism and slavery.

15 Carl T. Bogus, Buckley: William F. Buckley Jr. and the Rise of American Conservatism (New York, Bloomsbury, 2011), p.13. Also see the forthcoming work by Heather Hendershot, Open to Debate: How William F. Buckley Put Liberal America on the Firing Line (New York, Broadside Books, 2016).

16 Bogus, Buckley, p. 21.

17 Morrison, Playing in the Dark, p. 44.

18 For background on James Baldwin, see Weatherby, James Baldwin; Fred L. Standley and Louis H. Pratt (eds.), Conversations with James Baldwin (Jackson, MS, University Press of Mississippi, 1989); Leeming, James Baldwin; Lawrie Balfour, The Evidence of Things Not Said: James Baldwin and the Promise of American Democracy (Ithaca, N.Y., Cornell University Press, 2001); Herb Boyd, Baldwin's Harlem: A Biography of James Baldwin (New York, Atria Books, 2008); Cora Kaplan and Bill Schwarz (eds.), James Baldwin: America and Beyond (Ann Arbor, MI, University of Michigan Press, 2011); Douglas Field, All Those Strangers: The Art and Lives of James Baldwin (Oxford, Oxford University Press, 2015).

19 Rebecca Aanerud, "Now More Than Ever: James Baldwin and the Critique of White Liberalism," in Dwight A. McBride (ed.), James Baldwin Now (New York, NYU Press, 1999), p. 57.

20 Schultz, Buckley and Mailer, p. 100.

21 Craig Werner, "The Economic Evolution of James Baldwin," in Fred L. Standley and Nancy V. Burt (eds.), Critical Essays on James Baldwin (Boston, MA, G.K. Hall, 1988).

22 The "white backlash" grew out of the southern anti-segregation movement, growing in the north in the wake of the Watts Uprising in 1965 and the shift of the Civil Rights movement to the north and west. See Kevin M. Kruse, White Flight: Atlanta and the Making of Modern Conservatism (Princeton, N.J., Princeton University Press, 2005); J. Todd Moye, Let the People Decide: Black Freedom and White Resistance Movements in 
Sunflower County, Mississippi, 1945-1986 (Durham, N.C., University of North Carolina Press, 2006); George Lewis, Massive Resistance: The White Response to the Civil Rights Movement (New York, Oxford University Press, 2006); Matthew W. Hughey, "White Backlash in the 'Post-racial' United States," Ethnic and Racial Studies, $37: 5$ (2014), pp.721-30.

23 See Story Hinckley, “Texas: We Don't Need Academics to Fact-check Our Textbooks," The Christian Science Monitor, 19 November 2015, http://www.csmonitor.com/USA/ Education/2015/1119/Texas-We-don-t-need-academics-to-fact-check-our-textbooksvideo (accessed 8 September 2016).

24 S. Michael Halloran, "Aristotle's Concept of Ethos, or If Not His Somebody Else's," Rhetoric Review, 1:1 (1982), p. 60.

25 See David Brion Davis, Slavery and Human Progress (New York, Oxford University Press, 1986); Jill Lepore, The Name of War: King Philip's War and the Origins of American Identity (New York, Vintage, 1998).

26 I define modernity as the set of historical processes arising after the 1500s, including colonialism, capitalism, the Atlantic slave system, the enlightenment, nationalism, and imperialism. My framework builds upon Mark Levine's "modernity matrix," see Mark Levine, Overthrowing Geography: Jaffa, Tel Aviv, and the Struggle for Palestine (Berkeley, CA, University of California Press, 2005).

27 Standley and Pratt (eds.), Conversations with James Baldwin, p. 191.

28 Ibid., pp. 191-2.

29 For more on Baldwin and "innocence," see Balfour, The Evidence of Things Not Said.

30 Greg Grandin, "Living in Revolutionary Times: Coming to Terms with the Violence of Latin America's Long Cold War," in Greg Grandin and Gilbert M. Joseph (eds.), A Century of Revolution: Insurgent and Counterinsurgent Violence During Latin America's Long Cold War (Durham, N.C., Duke University Press, 2010), p. 8.

31 Standley and Pratt (eds.), Conversations with James Baldwin, p. 192.

32 Morrison, Playing in the Dark, p. 52.

33 James Baldwin and Margaret Mead, A Rap on Race (New York, Dell Publishing, 1971), pp. 197-8. For the Faulkner quote, see William Faulkner, Requiem for a Nun (New York, Random House, 1951), p. 73.

34 Michael Omi and Howard Winant, Racial Formation in the United States: From the 1960s to the 1990s (New York, Routledge, 2nd ed., 1994), p. 70.

35 For the "disavowal" of history, see Walter L. Hixson, American Settler Colonialism: A History (New York, Palgrave Macmillan, 2013), p. 12. For "silencing" history, see Michel-Rolph Trouillot, Silencing the Past: Power and the Production of History (Boston, MA, Beacon Press, 1995).

36 See Saidiya Hartman, Lose Your Mother: A Journey Along the Atlantic Slave Route (New York, Farrar, Straus, and Giroux, 2007), p. 6.

37 Wilderson, Red, White \& Black, p. 80. See also Steve Martinot and Jared Sexton, "The Avant-Garde of White Supremacy," Social Identities: Journal for the Study of Race, Nation and Culture, 9:2 (2003), p. 172.

38 See Matthew Frye Jacobson, Roots Too: White Ethnic Revival in Post-Civil Rights America (Cambridge, MA, Harvard University Press, 2006).

39 Shultz, Buckley and Mailer, p. 118.

40 Debate: Baldwin vs. Buckley.

41 Ibid. 
42 “An Interview with James Baldwin," Esquire, July 1968, p. 52.

43 Debate: Baldwin vs. Buckley.

44 See Freund, Colored Property.

45 For the relationship to civil society, see Frank Wilderson III, "Gramsci's Black Marx: Whither the Slave in Civil Society?," Social Identities, 9:2 (2003), pp. 225-40.

46 Michel-Rolph Trouillot, "The Otherwise Modern: Caribbean Lessons from the Savage Slot," in Bruce M. Knauft (ed.), Critically Modern: Alternatives, Alterities, Anthropologies (Bloomington, IN, Indiana University Press, 2002), p. 220.

47 “The Week," National Review, 24 August 1957, p. 149.

48 For "self rule," see Robert H. Wiebe, Self Rule: A Cultural History of American Democracy (Chicago, University of Chicago Press, 1995).

49 For zip coon, see Donald Bogle, Toms, Coons, Mulattoes, Mammies, \& Bucks: An Interpretive History of Blacks in American Films (New York, Continuum, 2009).

50 Omi and Winant, Racial Formation in the United States, p. 66.

51 George Lipsitz, The Possessive Investment in Whiteness: How White People Profit from Identity Politics (Philadelphia, PA, Temple University Press, rev. ed., 2006), p. 50.

52 Nikhil Pal Singh, Black is a Country: Race and the Unfinished Struggle for Democracy (Cambridge, MA, Harvard University Press, 2004), p. 10.

53 Stephen Steinberg, “Race Relations': The Problem with the Wrong Name," New Politics, 8:2 (2001), http://newpol.org/node/20 (accessed 30 May 2012).

54 Nathan Glazer and Daniel P. Moynihan, Beyond the Melting Pot: The Negroes, Puerto Ricans, Jews, Italians, and Irish of New York City (Cambridge, MA, M.I.T. Press, 1963).

55 Jacobson, Roots Too, p. 177.

56 Ibid.

57 Rick Perlstein, Nixonland: The Rise of a President and the Fracturing of America (New York, Scribner, 2008), pp. 459-60.

58 Nathan Glazer, Affirmative Discrimination: Ethnic Inequality and Public Policy (Cambridge, MA, Harvard University Press, 1975).

59 Transcript of "Black Power," Firing Line, 7 March 1967.

60 Ibid., pp. 3-4.

61 Jacobson, Roots Too, p. 178.

62 See Martin Barker, The New Racism: Conservatives and the Ideology of the Tribe (London, Junction Books, 1981), p.3.

63 Ibid., p. 10.

64 Errol Lawrence, "Just Plain Common Sense: The 'Roots' of Racism," in Centre for Contemporary Cultural Studies (ed.), The Empire Strikes Back: Race and Racism in 70s Britain (London, Routledge, 1982), p. 82.

65 Etienne Balibar, "Is There a 'Neo-Racism'?, in Etienne Balibar and Immanuel Wallerstein, Race, Nation, Class: Ambiguous Identities, trans. Chris Turner (London, Verso, 1991), p. 21.

66 James Baldwin, “Nobody Knows My Name," in Collected Essays, ed. Toni Morrison (New York, Library of America, 1998), pp. 219-20.

67 “The Week," National Review, 24 August 1957, p. 149.

68 Buckley, "Our Mission Statement."

69 James Baldwin, No Name in the Street (New York, Vintage, 1972).

70 Ibid., p. 46.

71 Standley and Pratt (eds.), Conversations with James Baldwin, pp. 191-2. 


\section{Works Cited}

“The American Dream and the American Negro," New York Times, 7 May 1965, SM32.

"Black Power," Firing Line, 7 March 1967.

"An Interview with James Baldwin," Esquire, July 1968, p. 52.

“The Week," National Review, 24 August 1957, p. 149.

Aanerud, Rebecca, "Now More Than Ever: James Baldwin and the Critique of White Liberalism," in Dwight A. McBride (ed.), James Baldwin Now (New York, NYU Press, 1999), pp. 56-74.

Baldwin, James, No Name in the Street (New York, Vintage, 1972).

_ "Nobody Knows My Name," in Collected Essays, ed. Toni Morrison (New York, Library of America, 1998), pp. 131-285.

Baldwin, James, and Nikki Giovanni, A Dialogue (Philadelphia, PA, J.B. Lippincott, 1973).

Baldwin, James, and Margaret Mead, A Rap on Race (New York, Dell Publishing, 1971).

Balfour, Lawrie, The Evidence of Things Not Said: James Baldwin and the Promise of American Democracy (Ithaca, N.Y., Cornell University Press, 2001).

Balibar, Etienne, “Is There a 'Neo-Racism'?," in Etienne Balibar and Immanuel Wallerstein, Race, Nation, Class: Ambiguous Identities, trans. Chris Turner (London, Verso, 1991), pp. 17-28.

Barker, Martin, The New Racism: Conservatives and the Ideology of the Tribe (London, Junction Books, 1981).

Bogle, Donald, Toms, Coons, Mulattoes, Mammies, \& Bucks: An Interpretive History of Blacks in American Films (New York, Continuum, 2009).

Bogus, Carl T., Buckley: William F. Buckley Jr. and the Rise of American Conservatism (New York, Bloomsbury, 2011).

Boyd, Herb, Baldwin's Harlem: A Biography of James Baldwin (New York, Atria Books, 2008).

Braudel, Fernand, On History, trans. Sarah Matthews (Chicago, University of Chicago Press, 1980).

Buckley, Jr., William F., “Our Mission Statement,” National Review, 19 November 1955, http://www.nationalreview.com/article/223549/our-mission-statement-william-fbuckley-jr (accessed 8 September 2016).

Burke, Peter, The French Historical Revolution: The Annales School 1929-2014 (Stanford, CA, Stanford University Press, 2nd ed., 2015).

Davis, David Brion, Slavery and Human Progress (New York, Oxford University Press, 1986).

Debate: Baldwin vs. Buckley, National Educational Television Network, February 1965, https://www.youtube.com/watch? $\mathrm{v}=\mathrm{oFeoS} 41 \mathrm{xe} 7 \mathrm{w}$ (accessed 8 September 2016).

Faulkner, William, Requiem for a Nun (New York, Random House, 1951).

Field, Douglas, All Those Strangers: The Art and Lives of James Baldwin (Oxford, Oxford University Press, 2015).

Freund, David M. P., Colored Property: State Policy \& White Racial Politics in Suburban America (Chicago, University of Chicago Press, 2007).

Glazer, Nathan, Affirmative Discrimination: Ethnic Inequality and Public Policy (Cambridge, MA, Harvard University Press, 1975).

Glazer, Nathan, and Daniel P. Moynihan, Beyond the Melting Pot: the Negroes, Puerto Ricans, Jews, Italians, and Irish of New York City (Cambridge, MA, M.I.T. Press, 1963). 
Grandin, Greg, "Living in Revolutionary Times: Coming to Terms with the Violence of Latin America's Long Cold War," in Greg Grandin and Gilbert M. Joseph (eds.), A Century of Revolution: Insurgent and Counterinsurgent Violence During Latin America's Long Cold War (Durham, N.C., Duke University Press, 2010), pp. 1-42.

Halloran, S. Michael, "Aristotle's Concept of Ethos, or If Not His Somebody Else's," Rhetoric Review, 1:1 (1982), pp. 58-63.

Hartman, Saidiya, Lose Your Mother: A Journey Along the Atlantic Slave Route (New York, Farrar, Straus, and Giroux, 2007).

Hendershot, Heather, Open to Debate: How William F. Buckley Put Liberal America on the Firing Line (New York, Broadside Books, 2016).

Hinckley, Story, “Texas: We Don't Need Academics to Fact-check Our Textbooks," The Christian Science Monitor, 19 November 2015, http://www.csmonitor.com/USA/ Education/2015/1119/Texas-We-don-t-need-academics-to-fact-check-our-textbooksvideo (accessed 8 September 2016).

Hixson, Walter L., American Settler Colonialism: A History (New York, Palgrave Macmillan, 2013).

Hughey, Matthew W., "White Backlash in the 'Post-racial' United States," Ethnic and Racial Studies, 37:5 (2014), pp.721-30.

Hunt, Lynn, "French History in the Last Twenty Years: The Rise and Fall of the Annales Paradigm," Journal of Contemporary History, 21:2 (1986), pp. 209-24.

Jacobson, Matthew Frye, Roots Too: White Ethnic Revival in Post-Civil Rights America (Cambridge, MA, Harvard University Press, 2006).

Kaplan, Cora, and Bill Schwarz (eds.), James Baldwin: America and Beyond (Ann Arbor, MI, University of Michigan Press, 2011).

Katznelson, Ira, When Affirmative Action Was White: An Untold History of Racial Inequality in Twentieth-Century America (New York, W.W. Norton, 2005).

Kruse, Kevin M., White Flight: Atlanta and the Making of Modern Conservatism (Princeton, N.J., Princeton University Press, 2005).

Lawrence, Errol, "Just Plain Common Sense: The 'Roots' of Racism," in Centre for Contemporary Cultural Studies (ed.), The Empire Strikes Back: Race and Racism in 70s Britain (London, Routledge, 1982).

Leeming, David, James Baldwin: A Biography (New York, Alfred A. Knopf, 1994).

Lepore, Jill, The Name of War: King Philip's War and the Origins of American Identity (New York, Vintage, 1998).

Levine, Mark, Overthrowing Geography: Jaffa, Tel Aviv, and the Struggle for Palestine (Berkeley, CA, University of California Press, 2005).

Lewis, George, Massive Resistance: The White Response to the Civil Rights Movement (New York, Oxford University Press, 2006).

Lipsitz, George, The Possessive Investment in Whiteness: How White People Profit from Identity Politics (Philadelphia, PA, Temple University Press, rev. ed., 2006).

Martinot, Steve, and Jared Sexton, “The Avant-Garde of White Supremacy," Social Identities: Journal for the Study of Race, Nation and Culture, 9:2 (2003), pp. 169-81.

Megill, Allan, "Coherence and Incoherence in Historical Studies: From the Annales School to the New Cultural History," New Literary History, 35:2 (2004), pp. 207-31.

Morrison, Toni, Playing in the Dark: Whiteness and the Literary Imagination (New York, Vintage, 1992).

Moye, J. Todd, Let the People Decide: Black Freedom and White Resistance Movements in 
Sunflower County, Mississippi, 1945-1986 (Durham, N.C., University of North Carolina Press, 2006).

Oliver, Melvin L., and Thomas M. Shapiro, Black Wealth, White Wealth: A New Perspective on Racial Inequality (New York, Routledge, 2006).

Omi, Michael, and Howard Winant, Racial Formation in the United States: From the 1960s to the 1990s (New York, Routledge, 2nd ed., 1994).

Patterson, James. The Eve of Destruction: How 1965 Transformed America (New York, Basic Books, 2012).

Perlstein, Rick, Nixonland: The Rise of a President and the Fracturing of America (New York, Scribner, 2008).

Robinson, Cedric J., Black Marxism: The Making of the Black Radical Tradition (Chapel Hill, N.C., University of North Carolina Press, 2000).

Schultz, Kevin M., Buckley and Mailer: The Difficult Friendship That Shaped the Sixties (New York, W.W. Norton, 2015).

Sexton, Jared. Amalgamation Schemes: Antiblackness and the Critique of Multiracialism (Minneapolis, MN, University of Minnesota Press, 2008).

Singh, Nikhil Pal, Black is a Country: Race and the Unfinished Struggle for Democracy (Cambridge, MA, Harvard University Press, 2004).

Standley, Fred L., and Louis H. Pratt (eds.), Conversations with James Baldwin (Jackson, MS, University Press of Mississippi, 1989).

Steinberg, Stephen, Turning Back: The Retreat from Racial Justice in American Thought and Policy (Boston, MA, Beacon Press, 1995).

_ “Race Relations': The Problem with the Wrong Name," New Politics, 8:2 (2001). http://newpol.org/node/20 (accessed 30 May 2012).

Trouillot, Michel-Rolph, Silencing the Past: Power and the Production of History (Boston, MA, Beacon Press, 1995).

"The Otherwise Modern: Caribbean Lessons from the Savage Slot," in Bruce M.

Knauft (ed.), Critically Modern: Alternatives, Alterities, Anthropologies (Bloomington, IN, Indiana University Press, 2002).

Weatherby, W. J., James Baldwin: Artist on Fire (New York, Donald I. Fine, 1989).

Werner, Craig, "The Economic Evolution of James Baldwin," in Fred L. Standley and Nancy V. Burt (eds.), Critical Essays on James Baldwin (Boston, MA, G.K. Hall, 1988).

Wiebe, Robert H., Self Rule: A Cultural History of American Democracy (Chicago, University of Chicago Press, 1995).

Wilderson, Frank, III, “Gramsci’s Black Marx: Whither the Slave in Civil Society?, Social Identities, 9:2 (2003), pp. 225-40.

- Red, White \& Black: Cinema and the Structure of U.S. Antagonisms (Durham, N.C., Duke University Press, 2010).

\section{Contributor's Biography}

Daniel Robert McClure received his Ph.D. in History from the University of California, Irvine, in 2013. He is interested in the relationship between culture and economics in the post-Second World War United States and African Diaspora, particularly in the context of the centuries-old processes of modernity (colonialism, imperialism, capitalism, the Atlantic slave system, the enlightenment, and nationalism/the nation-state). His scholarship has been published in The Sixties: A Journal of History, Politics and Culture, Journal 
of the West, and the National Political Science Review. He is currently writing two books: Historical Theory and Methods through Popular Music, 1970-2000: Those are the New Saints (under contract with Palgrave Macmillan) and Winter in America: A Cultural History of Neoliberalism, 1960s-1980s (under consideration at the University of North Carolina Press). McClure teaches at California State University, Fullerton, Chapman University, and the University of California, Irvine. 